\title{
Modeling the Impact of Atmospheric Warming on Staple Crop Growth in China in the 1960s and 2000s
}

\author{
Qing Zhang ${ }^{1}$, Wen Zhang ${ }^{1} * \mathbb{C}$, Yongqiang $\mathrm{Yu}^{1}$, Tingting $\mathrm{Li}^{1,2}$ and Lijun $\mathrm{Yu}^{1}$ \\ 1 State Key Laboratory of Atmospheric Boundary Layer Physics and Atmospheric Chemistry (LAPC), \\ Institute of Atmospheric Physics, Chinese Academy of Sciences, Beijing 100029, China; \\ zhangqing@mail.iap.ac.cn (Q.Z.); yuyq@mail.iap.ac.cn (Y.Y.); litingting@mail.iap.ac.cn (T.L.); \\ yulj@mail.iap.ac.cn (L.Y.) \\ 2 Southern Marine Science and Engineering Guangdong Laboratory (Zhuhai), Zhuhai 519000, China \\ * Correspondence: zhw@mail.iap.ac.cn
}

Citation: Zhang, Q.; Zhang, W.; Yu, Y.; Li, T.; Yu, L. Modeling the Impact of Atmospheric Warming on Staple Crop Growth in China in the 1960s and 2000s. Atmosphere 2021, 12, 36. https://doi.org/10.3390/atmos1201 0036

Received: 23 October 2020 Accepted: 27 December 2020 Published: 30 December 2020

Publisher's Note: MDPI stays neutral with regard to jurisdictional clai$\mathrm{ms}$ in published maps and institutional affiliations.

Copyright: ( 2020 by the authors. Licensee MDPI, Basel, Switzerland. This article is an open access article distributed under the terms and conditions of the Creative Commons Attribution (CC BY) license (https:// creativecommons.org/licenses/by/ $4.0 /)$.

\begin{abstract}
Responses of crop growth to climate warming are fundamental to future food security. The response of crops to climate change may be subtly different at their growing stages. Close insights into the differentiated stage-dependent responses of crops are significantly important in making adaptive adjustments of crops' phenological optimization and cultivar improvement in diverse cropping systems. Using the Agro-C model, we studied the influence of past climate warming on crops in typical cropping systems in China. The results showed that while the temperature had increased distinctly from the 1960s to 2000s, the temperature frequency distributions in the growth season of crops moved to the high-temperature direction. The low temperature days during the crop growth periods that suppress crop growth decreased in the winter wheat area in North and East China, rice and maize areas in Northeast China, and the optimum temperature days increased significantly. As a result, the above ground biomass (AGB) of rice and maize in Northeast China and winter wheat in North and East China increased distinctly, while that of rice in South China had no significant change. A comparison of the key growth periods before and after heading (silking) showed that the warming before heading (silking) made a great contribution to the increase in the AGB, especially for winter wheat.
\end{abstract}

Keywords: Agro-C model; climate change; crop productivity; temperature response

\section{Introduction}

Under the influence of climate change and frequent extreme climate events, the photosynthetic production of crops faces great challenges [1]. To stabilize crop productivity and essentially ensure food security, it is thus necessary to make effective adjustments to agronomies depending on prediction of crop growth responses to climate change [2]. We need to assess the crop photosynthesis production response to climate change, on the one hand, in order to ensure food security in China [3], and on the other hand to increase the capacity for agroecosystems to manage atmospheric $\mathrm{CO}_{2}$, thereby increasing carbon sink potential.

Field observations and statistical data show that climate change, fertilization, irrigation and crop varieties in China have undergone significant changes in recent decades [4]. The climatic elements, e.g., temperature, precipitation, solar radiation and atmospheric $\mathrm{CO}_{2}$ concentration all affect the photosynthetic production of crops to different degrees [4-9]. From 1955 to 2000, the average annual maximum and minimum temperatures in China increased by 0.13 and $0.32{ }^{\circ} \mathrm{C}$ per decade, respectively [10]. In 1980, the rate of nitrogen fertilizer application for crop production was $9.4 \mathrm{Mt}$; it increased to $23.8 \mathrm{Mt}$ by 2011 (National Bureau of Statistics, China, 2013). Meanwhile, the photosynthetic efficiency of leaf nitrogen, which reflects crop variety change, also showed a recognizable increase $[3,11]$. 
To date, the effects of climate change on the photosynthetic production of crops in China have been widely evaluated with crop models, statistical analyses of historical data, field observations, satellite remote sensing data and other methods $[4,7-9,12,13]$. In different regions, the effects of climate warming on crop productivity of China vary greatly, resulting in changing growth periods and spatial moving of different rotation systems [14], such as the southward shift of the northern limit of the double-cropping system and the northward shift of the northern limit of the triple-cropping system [15]. The modelling approaches have been applied to simulate crop photosynthesis production at different spatial scales, including at field $[6,16,17]$, regional $[5,18-21]$, national $[6,22,23]$ and global scales [24]. The impacts of climate change on crop productivity, growth periods and planting systems have also been assessed with the models. Taking data for the period of 1984-2003 from the China Rural Statistical Yearbook of the National Bureau of Statistics and observations of annual average temperature for the same period, Liu and Lin [25] concluded that climate change, characterized by temperature increases, has a pronounced positive effect on crop production in Northeast China, but negative effects in North, Northwest and Southwest China. Warming prolongs the growing period of crops in the cold regions with poor thermal conditions, which is beneficial to crop variety selection and planting structure adjustment. It is unfavorable for crops with short growth periods, as warming accelerates their growth rate and shortens their growth period. For a $1^{\circ} \mathrm{C}$ increase in the average temperature during the crop growth period, the rice growth period is shortened by 7-8 days, while that of winter wheat is shortened by 17 days, which is not beneficial for the accumulation of crop dry matter. Warming thus accelerates crop growth and shortens the growth period, ultimately leading to decreased crop production [26].

Below the optimum temperature of crops, which is usually the case in temperate regions such as China, increasing temperature stimulates both crop photosynthesis and respiration that contribute contradictorily to the accumulation of carbon for crop growth. When the increment of photosynthesis by warming is larger than that of respiration, crop growth will benefit from the temperature increase; otherwise, there will be a reduction in crop productivity. Climate warming has been perceived to have negative impacts on crop production in China, considering that climate warming has the effects of shortening the duration of crop growing period [27-29]. However, observations showed no decline of staple food crop production in China during the period from the 1960s to 2000s. This can be attributed to the improvements of agronomies in recent decades, e.g., enhanced fertilizer application, more efficient field irrigation and variety renewals, etc. In addition, the different responses of crop photosynthesis and respiration to the increasing temperatures might also be an important reason for it. In this paper, the calibrated Agro-C model was used to compare simulation results for the 1960s (1960-1969) and 2000s (2000-2009) on the five sites in four typical rotation areas in Northeast, North, East and Central China. The main reason that we compared temperature and made model simulation during the 1960s and 2000s is that the field observational data we used to validate the model are to the year 2010 [30] and back to the year 1980 [31]. We primarily confined our study to the time duration of model validation. The extending from 1980 to 1960 is on the assumption that from 1960 to 1980, the agronomy of China crop production changed much less than after 1980 so that the model is applicable when we need also a long time period for the study of climate warming effects on crops.

The main objectives of this research were to: (1) analyze the regional crop photosynthetic productivity responses to temperature increase in different crop rotation areas in China; (2) investigate the main causes of such responses; (3) quantify the contribution of climate warming to crop photosynthetic productivity before and after heading (silking).

\section{Methods}

\subsection{Research Area}

China is a nation of multiple climate zones that support diverse cropping systems. Rice, wheat and maize are the three staple foods in China. Rice is the staple food for more 
than $65 \%$ of the Chinese population, accounting for $40 \%$ of caloric intake in China (State Environmental Protection Administration (SEPA), 2003) [17]. Wheat is also a staple food for half of the world's population, and the second-largest crop in China [32]. Maize is one of the staple crops, also the most vulnerable crop to climate change among the staple crops in China [33]. These three cereal crops accounted for approximately $54 \%$ of the total sowing area and $89 \%$ of the total grain yield in China until 2009 [8,34]. These sites, Changshu $\left(31.53^{\circ} \mathrm{N}, 120.68^{\circ} \mathrm{E}\right)$ with a winter wheat rice rotation, Taoyuan $\left(28.92^{\circ} \mathrm{N}, 111.45^{\circ} \mathrm{E}\right)$ with a double rice rotation, Fengqiu $\left(35^{\circ} \mathrm{N}, 114.4^{\circ} \mathrm{E}\right)$ with a winter wheat maize rotation, Sanjiang $\left(47.58^{\circ} \mathrm{N}, 113.52^{\circ} \mathrm{E}\right)$ with single rice cultivation and Hailun $\left(47.43^{\circ} \mathrm{N}, 126.63^{\circ} \mathrm{E}\right)$ with single maize cultivation, represent the typical cropping systems of the main cultivation regions of China. We conducted the analysis at the 5 sites in four typical crop rotation areas of China (Figure 1) to simulate crop productivity in different crop rotation systems. Detailed information on each site is shown in Table 1.

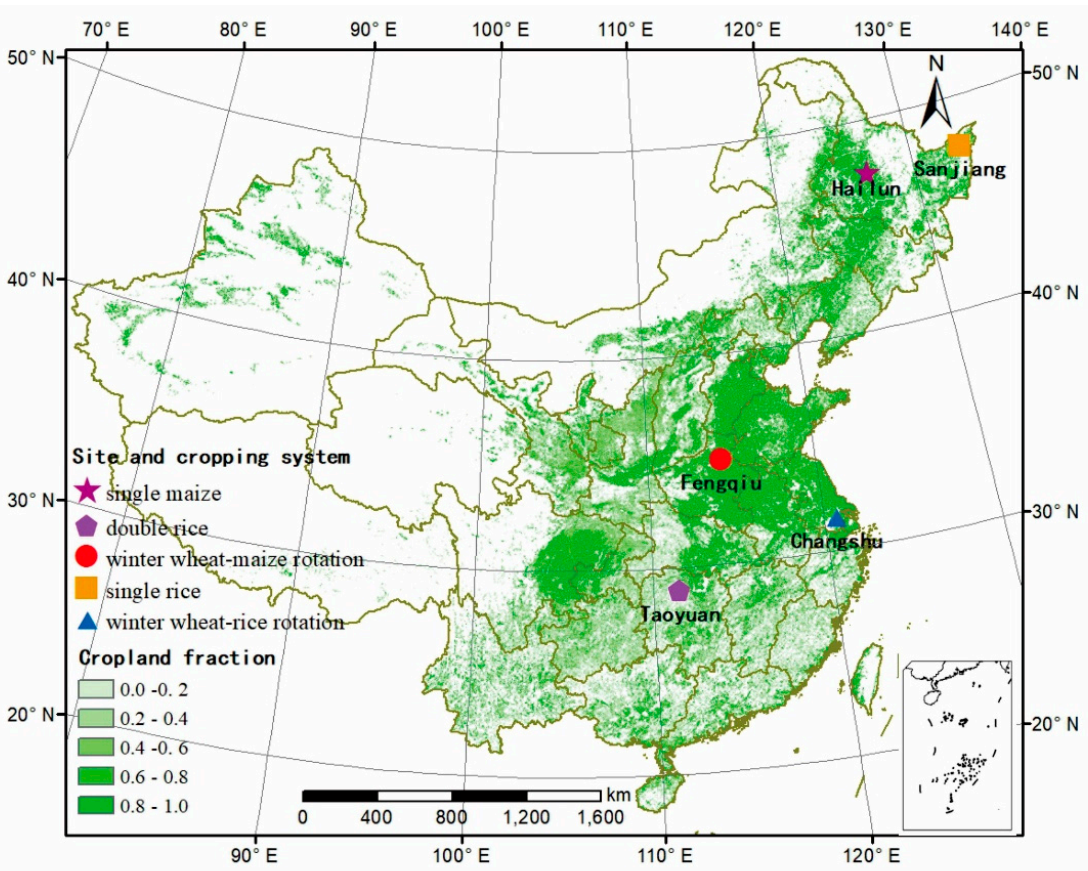

Figure 1. Locations of the sites with different rotation systems. Overlap of the symbols stands for crop rotations: maize/wheat rotation at Fengqiu, rice/wheat rotations in Changshu and rice/rice rotation at Taoyuan. The green colored background shows the distribution of cropland in China in 2015 (http:/ / www.resdc.cn/lds.aspx).

\subsection{The Modeling Approach}

We used the Agro-C model [31], which is a process-based model for simulating crop photosynthesis, respiration and other processes involved in crop growth and carbon/nitrogen dynamics in soils. The model runs on a daily time step, and the inputs of it are climatic, edaphic, atmospheric $\mathrm{CO}_{2}$ concentration, crop calendar and field management data. The outputs of the model include crop biomass, leaf area index (LAI), gross primary productivity (GPP), crop respiration (RA) and net primary productivity (NPP). The model used in the present study has two functional modules to simulate crop photosynthesis and respiration. These modules incorporate impacts of the environmental variables of temperature, solar radiation, soil moisture and atmospheric $\mathrm{CO}_{2}$ concentration on the crop growth, but the influence of pests and diseases cannot be captured at present. The effect of air temperature on photosynthesis is expressed by a piecewise function, and is determined by the lower and upper temperature limits, and optimum temperature subject to specific crop varieties. The optimum temperatures for the photosynthesis of rice, wheat and maize are 29,18 and $30^{\circ} \mathrm{C}$, respectively [31]. The Agro-C model contains 29 basic formulas. For 
more detailed information about the model, the reader is advised to refer to Huang et al. (2009) [31]. The main processes are as follows:

$$
G P P_{i}=0.0432 \times P_{i} \times D L_{i}
$$

where GPP $\left(\mathrm{g} \mathrm{C} \mathrm{m}^{-2} \mathrm{~d}^{-1}\right)$ is the gross primary production and $P\left(\mu \mathrm{mol} \mathrm{CO}_{2} \mathrm{~m}^{-2} \mathrm{~s}^{-1}\right)$ is the photosynthetic rate. $D L(h)$ is the day length:

$$
P_{i}=\frac{P M_{i} \times \overline{P A R_{i}}}{\beta+\overline{P A R_{i}}} \times f\left(T_{i}\right) \times f\left(W_{i}\right) \times f\left(\mathrm{CO}_{2}\right)
$$

where $P M\left(\mu \mathrm{mol} \mathrm{CO}_{2} \mathrm{~m}^{-2} \mathrm{~s}^{-1}\right)$ is the canopy photosynthetic rate at light saturation determined by the green leaf nitrogen content ( $N L, \mathrm{~g} \mathrm{~N} \mathrm{~m}^{-2}$ of ground); $\beta$ is a coefficient that determines the shape of the photosynthetic active radiation $(P A R)$-response curve of photosynthesis; $\overline{P A R}\left(\mu \mathrm{mol} \mathrm{m} \mathrm{m}^{-2} \mathrm{~s}^{-1}\right)$ represents the mean value of PAR intercepted by the crop canopy; $f(T), f(W)$ and $f\left(\mathrm{CO}_{2}\right)$, are the impacts of air temperature, soil moisture and atmospheric $\mathrm{CO}_{2}$ concentration on photosynthesis, respectively.

$$
\begin{gathered}
P M_{i}=\alpha \times N L_{i-1} \\
\overline{P A R_{i}}=\frac{(1-\rho) \times P A R_{0 i}}{k \times L A I_{i-1}}\left[1-\exp \left(-k \times L A I_{i-1}\right)\right]
\end{gathered}
$$

where $\alpha$ is a coefficient representing the photosynthetic capacity per unit canopy leaf nitrogen. $\rho$ is canopy reflectance, set at $6 \%$, and $k$ is an irradiance extinction coefficient that varies with crop development [31]. $P A R_{0}$ represents the PAR above the crop canopy. $L A I$ $\left(\mathrm{m}^{2} \mathrm{~m}^{-2}\right)$ is the green leaf area index determined by:

$$
\begin{aligned}
& L A I_{i}=\left\{\begin{array}{l}
\leq C D S\left(P L_{i} \times\left(G P P_{i}-R A_{i}\right) / 0.45\right) \times S L A-D L A I_{i}(i \leq C D S) \\
\frac{\sum_{i=1}\left(L A I_{m a x}\right.}{1+\sigma \times\left(D V I_{i}-1\right)^{2}}(i>C D S)
\end{array}\right. \\
& D V I_{i}=\frac{\sum_{i=1}^{\leq n} T_{a i}}{A T}
\end{aligned}
$$

where $P L$ represents the fraction of photosynthesis partitioned to leaves. $S L A$ is the specific leaf area $\left(\mathrm{m}^{2} \mathrm{~kg}^{-1}\right)$. DLAI represents the yellow leaves due to senescence. $C D S$ represents a certain developmental stage of a crop, such as heading of rice. $L A I_{\max }$ represents the $L A I$ at the CDS phase. DVI(developmental index) is the crop developmental index. $\sigma$ is a coefficient. The effects of air temperature, soil moisture and atmospheric $\mathrm{CO}_{2}$ concentration on photosynthesis are as follows:

$$
f\left(T_{i}\right)=\left\{\begin{array}{l}
0 \\
\left(\frac{T_{d i}-T_{L}}{T_{0}-T_{L}}\right)^{(1+\gamma)} \times\left(\frac{T_{U}-T_{d i}}{T_{U}-T_{0}}\right)^{(1-\gamma)} \quad \text { for } T_{L} \leq T_{d i} \leq T_{U}
\end{array}\right.
$$

where $T_{L}, T_{U}$ and $T_{O}$ are the base and maximum temperature limits, and optimum temperature $\left({ }^{\circ} \mathrm{C}\right)$, respectively. $T_{d}$ is the daytime air temperature $\left({ }^{\circ} \mathrm{C}\right) \cdot \gamma$ is a coefficient that determines the shape of the temperature response curve of photosynthesis. Table 2 listed the three temperatures for crop photosynthetic growth measured: $T_{L}, T_{O}, T_{U}$ and the range of $T_{O}$ (within this range, $f(T) \geq 0.95$, see Equation (7)). These temperature thresholds vary from crop to crop $[35,36]$. When ambient temperatures are lower than the base temperature or higher than the maximum temperature, crop growth is inhibited, and when ambient temperatures fall within the optimum temperature range, crop photosynthetic efficiency is also optimistic, which was described in the Agro-C model [31]. 
Table 1. Detailed information of the studied regions in Chinese Ecosystem Research Network (CERN).

\begin{tabular}{|c|c|c|c|c|c|c|c|c|c|c|c|c|c|}
\hline \multirow[t]{2}{*}{ Location } & \multirow{2}{*}{$\begin{array}{c}\text { Site } \\
\text { (Province) }\end{array}$} & \multirow[t]{2}{*}{ Longitude } & \multirow[t]{2}{*}{ Latitude } & \multirow[t]{2}{*}{$\begin{array}{l}\text { Altitude } \\
\text { (m) }\end{array}$} & \multirow{2}{*}{$\begin{array}{c}\text { Annual } \\
\text { Mean } \\
\text { Temper- } \\
\text { ature } \\
\left({ }^{\circ} \mathrm{C}\right)\end{array}$} & \multirow{2}{*}{$\begin{array}{l}\text { Annual } \\
\text { Total } \\
\text { Precipi- } \\
\text { tation } \\
(\mathrm{mm})\end{array}$} & \multirow[t]{2}{*}{$\begin{array}{c}\text { Total N } \\
(\%)\end{array}$} & \multirow[t]{2}{*}{$\mathrm{pH}$} & \multirow[t]{2}{*}{ Crop } & \multirow{2}{*}{$\begin{array}{l}\text { Sown } \\
\text { Area * } \\
\text { (hectare) }\end{array}$} & \multicolumn{3}{|c|}{$\begin{array}{c}\text { Developmental Index (DVI) (Month/Date) } \\
\text { (Rice: Transplanting-Heading-Maturity; Wheat: } \\
\text { Emergence-Heading-Maturity; Maize: } \\
\text { Emergence-Silking-Maturity) }\end{array}$} \\
\hline & & & & & & & & & & & $\begin{array}{c}\text { Emergence } \\
\text { (Transplanting) }\end{array}$ & $\begin{array}{l}\text { Heading } \\
\text { (Silking) }\end{array}$ & Maturity \\
\hline \multirow{2}{*}{ East China } & \multirow{2}{*}{$\begin{array}{c}\text { Changshu } \\
\text { (Jiangsu) }\end{array}$} & \multirow{2}{*}{$31^{\circ} 32^{\prime} \mathrm{N}$} & \multirow{2}{*}{$120^{\circ} 41^{\prime} \mathrm{E}$} & \multirow[t]{2}{*}{1.3} & \multirow{2}{*}{15.4} & \multirow{2}{*}{1095} & \multirow{2}{*}{2.33} & \multirow{2}{*}{6.90} & Rice & 1351 & $6 / 14$ & $8 / 28$ & $10 / 22$ \\
\hline & & & & & & & & & $\begin{array}{l}\text { Winter } \\
\text { wheat }\end{array}$ & 1339 & $10 / 28$ & $4 / 15$ & $5 / 29$ \\
\hline \multirow{2}{*}{$\begin{array}{l}\text { South } \\
\text { China }\end{array}$} & \multirow{2}{*}{$\begin{array}{l}\text { Taoyuan } \\
\text { (Hunan) }\end{array}$} & \multirow{2}{*}{$28^{\circ} 55^{\prime} \mathrm{N}$} & \multirow{2}{*}{$111^{\circ} 27^{\prime} \mathrm{E}$} & \multirow[t]{2}{*}{77.5} & \multirow{2}{*}{16.5} & \multirow{2}{*}{1353} & \multirow{2}{*}{1.31} & \multirow{2}{*}{5.44} & $\begin{array}{l}\text { Early } \\
\text { rice }\end{array}$ & 3482 & $4 / 26$ & $6 / 15$ & $7 / 10$ \\
\hline & & & & & & & & & Late rice & 4062 & $7 / 14$ & $9 / 2$ & $10 / 10$ \\
\hline \multirow{2}{*}{$\begin{array}{l}\text { North } \\
\text { China }\end{array}$} & \multirow{2}{*}{$\begin{array}{l}\text { Fengqiu } \\
\text { (Henan) }\end{array}$} & \multirow{2}{*}{$35^{\circ} 00^{\prime} \mathrm{N}$} & \multirow{2}{*}{$114^{\circ} 24^{\prime} \mathrm{E}$} & \multirow[t]{2}{*}{67.5} & \multirow{2}{*}{13.9} & \multirow{2}{*}{507} & 0.99 & 8.30 & $\begin{array}{l}\text { Winter } \\
\text { wheat }\end{array}$ & 3587 & $10 / 24$ & $4 / 20$ & $6 / 8$ \\
\hline & & & & & & & & & $\begin{array}{l}\text { Summer } \\
\text { maize }\end{array}$ & 2049 & $6 / 12$ & $8 / 7$ & $9 / 25$ \\
\hline Northeast & $\begin{array}{l}\text { Hailun } \\
\text { (Hei- } \\
\text { longjiang) }\end{array}$ & $47^{\circ} 26^{\prime} \mathrm{N}$ & $126^{\circ} 38^{\prime} \mathrm{E}$ & 240 & 1.3 & 531 & 2.30 & 5.64 & $\begin{array}{l}\text { Spring } \\
\text { maize }\end{array}$ & 9399 & $5 / 22$ & $7 / 24$ & $10 / 3$ \\
\hline China & $\begin{array}{l}\text { Sanjiang } \\
\text { (Hei- } \\
\text { longjiang) }\end{array}$ & $47^{\circ} 35^{\prime} \mathrm{N}$ & $133^{\circ} 31^{\prime} \mathrm{E}$ & 56.2 & 3.6 & 448 & 5.80 & 2.50 & $\begin{array}{l}\text { Single } \\
\text { rice }\end{array}$ & 10222 & $5 / 17$ & $7 / 29$ & $9 / 25$ \\
\hline
\end{tabular}




$$
f\left(W_{i}\right)=\left\{\begin{array}{l}
0 \\
\frac{W_{i}-W_{P}}{W_{l}-W_{P}} \\
1 \\
0.5 \times\left(1+\frac{W_{i}-1}{W_{u}-1}\right)
\end{array}\right.
$$

where $W_{p}$ is wilting moisture $\left(\mathrm{cm}^{3} \mathrm{~cm}^{-3}\right)$, and $W_{l}$ and $W_{u}$ are the lower and upper values of optimum soil moisture $\left(\mathrm{cm}^{3} \mathrm{~cm}^{-3}\right)$ for photosynthesis, respectively [31].

$$
f\left(\mathrm{CO}_{2}\right)=1+B \ln \left(\frac{C_{y}}{C_{0}}\right)
$$

where $B$ is 0.8 for $C 3$ crops and 0.4 for $C 4$ crops [31]; $C_{y}$ is the $\mathrm{CO}_{2}$ concentration for a given year and $C_{0}$ is $340 \mu \mathrm{mol} \mathrm{mol}^{-1}$.

Table 2. Base $\left(T_{L}\right)$, optimum $\left(T_{O}\right)$ and maximum $\left(T_{U}\right)$ temperatures for crop photosynthesis [31].

\begin{tabular}{ccccc}
\hline Crop & $\boldsymbol{T}_{\boldsymbol{L}}$ & $\begin{array}{c}\boldsymbol{T}_{\boldsymbol{O}} \\
\left({ }^{\circ} \mathbf{C}\right)\end{array}$ & $\begin{array}{c}\boldsymbol{T}_{U} \\
\left({ }^{\circ} \mathbf{C}\right)\end{array}$ & $\begin{array}{c}\text { Range of } \boldsymbol{T}_{\boldsymbol{O}}(f(\boldsymbol{T}) \geq \mathbf{0 . 9 5 )} \\
\left({ }^{\circ} \mathbf{C}\right)\end{array}$ \\
\hline Rice & 12 & 29 & 40 & $27-33$ \\
Winter wheat & 3 & 18 & 35 & $16-25$ \\
Maize & 9 & 30 & 42 & $26-33$ \\
\hline
\end{tabular}

The Agro-C model distinguishes crop-specific parameters for different crops. These parameters include the harvest index $(\mathrm{HI})$, the fraction of photosynthate matter partitioned to roots and leaves (PR and PL), specific leaf area (SLA), the irradiance extinction coefficient and the photosynthetic capacity per unit canopy leaf nitrogen $(\alpha)$. In our previous study, the Agro-C model was used to simulate rice, wheat and maize. We mainly calibrated the three key parameters (SLA, PL and $\alpha$ ) of the Agro-C model, which are the most sensitive parameters. The parameters were calibrated with the crops' variety information. The calibrated parameters were shown in our previous published paper. For details, the reader is advised to refer to Zhang et al. (2017) [30].

In this study, we used the calibrated Agro- $C$ model to analyze the influence of past climate warming on crops in typical cropping systems in China. The response of crops in different rotation systems to temperature changes may have great regional differences. Therefore, we first tried to explain the changes in the frequency distribution of temperature during the growth period of crops in the 1960s and 2000s. Then, the gross primary productivity 9 GPP), autotrophic respiration (RA) and above ground biomass (AGB) of rice, wheat and maize in the 1960s and 2000s were simulated. The GPP denoted carbon accumulated by photosynthesis, RA denoted carbon lost by crop autotrophic respiration and AGB denoted the net accumulation of crops above ground biomass. The effects of climate warming on crop growth in different rotation systems were reflected by comparing the simulation results of the two periods. Finally, we further analyzed the contribution of temperature change to crop productivity in key growth stages. Using heading (silking) as the boundary, two key crop growth periods ( 40 days before heading (silking) and from heading (silking) to maturity) were analyzed. By comparing the increase in GPP, RA and AGB in the vegetative growth period before heading to the reproductive growth period after heading, effects of environmental temperature changes in different periods on regional crop photosynthetic production were analyzed.

\subsection{Data Sources}

The details of the input data and data sources used in the study are shown in Table 3. The research period mainly included two parts, namely the period from 1961 to 1969 (1960s) and the period of 2000-2009 (2000s). The data analyzed for the 1960s and 2000s in this study were the ten-year average value over the two periods. The observed meteorological 
data of the five sites were obtained from the China Meteorological Administration, including the observed daily maximum and minimum temperature, daily solar radiation and precipitation of the 1960s and 2000s. To fill the data gap in observed solar radiation data, a method by Thornton et al. (2000) [37] was adopted to estimate daily solar radiation. The method was calibrated beforehand with historical observations from 11 meteorological sites in China to ensure its validity in Zhang et al. (2007) [38]. For more details about the method, the reader is referred to Thornton et al. (2000) [37] and Zhang et al. (2007) [38]. The atmospheric $\mathrm{CO}_{2}$ concentration data between 2000 and 2009 were obtained from the World Meteorological Organization (Table 3).

Table 3. Sources of input data.

\begin{tabular}{|c|c|c|}
\hline Input Data & Detailed Description & Source \\
\hline Meteorological data & $\begin{array}{l}\text { daily maximum, minimum and } \\
\text { mean air temperature }\left({ }^{\circ} \mathrm{C}\right) \text {, } \\
\text { precipitation }(\mathrm{mm}) \text {, solar radiation } \\
\left(\mathrm{MJ} \mathrm{m} \mathrm{m}^{-2} \mathrm{~d}^{-1}\right)\end{array}$ & $\begin{array}{l}\text { http: } \\
\text { //cdc.cma.gov.cn/home.do }\end{array}$ \\
\hline Soil data & $\begin{array}{l}\text { concentrations of organic carbon } \\
\text { and total nitrogen }(\mathrm{g} / \mathrm{kg}) \text {, sand and } \\
\text { clay fraction }(\%), \mathrm{pH}, \text { bulk density } \\
\qquad\left(\mathrm{g} \mathrm{cm}^{-3}\right)\end{array}$ & $\begin{array}{c}\text { Chinese Ecosystem } \\
\text { Research Network (CERN) }\end{array}$ \\
\hline & $\begin{array}{l}\text { dates of crop growth: Rice: } \\
\text { Transplanting-Heading-Maturity; }\end{array}$ & \\
\hline Developmental index & Wheat: & Chinese Ecosystem \\
\hline$(\mathrm{DVI})$ & $\begin{array}{c}\text { Emergence-Heading-Maturity; } \\
\text { Maize: }\end{array}$ & Research Network (CERN) \\
\hline Farming management & $\begin{array}{l}\text { Emergence-Silking-Maturity } \\
\text { timing and rates of fertilizer } \\
\text { application, manure inputs, crop } \\
\text { residue management, irrigation }\end{array}$ & $\begin{array}{c}\text { Chinese Ecosystem } \\
\text { Research Network (CERN) }\end{array}$ \\
\hline $\begin{array}{l}\text { Atmospheric } \mathrm{CO}_{2} \\
\text { concentration }\end{array}$ & & $\begin{array}{c}\text { World Meteorological } \\
\text { Organization } \\
\text { (https:/ / community.wmo.int/ } \\
\text { activity-areas/gaw) }\end{array}$ \\
\hline
\end{tabular}

The soil, crop and field management data between 2000 and 2009 were obtained from the Chinese Ecosystem Research Network (CERN), which contained 21 sites under different crop rotation systems. The rice sites included the main rice areas in Northeast China, North China, East China, Central China and South China, covering the main rice planting areas in China from north to south, namely, a single rice cropping system in Northeast China, a rice-wheat rotation system in East China and a double rice cropping system in Central and South China. The wheat sites included the spring wheat in Northeast and Northwest China, winter wheat in Southwest China, North China and East China. The maize sites included the summer maize in North China and spring maize in Northeast and Northwest China. These sites almost covered the typical rotation systems of rice, wheat and maize. The observations included crop calendar (sowing, heading, harvesting, etc.), LAI, leaf weight and aboveground and belowground biomass. The methods of irrigation and synthetic fertilizer application and the amounts of organic manure and residue retention were also recorded. The soil properties relevant to crop growth, i.e., the total soil nitrogen and organic carbon, bulk density, $\mathrm{pH}$ and sand/clay fractions, were site-specific. Each observation site consisted of 4-6 observation quadrates.

During simulation, except for the temperature data, the other input data for the two periods were based on input data for the 2000s and only considered the influence of temperature differences in the 1960s and 2000s on crop photosynthetic production to better reflect effects of temperature changes on crop photosynthetic production. 


\section{Results}

\subsection{Temperature Changes during Crop Growth}

Relative to the 1960s, temperatures did not change significantly during the summer maize growth period in Fengqiu in North China, but temperatures in other regions increased significantly during crop growth periods in the 2000s, and the temperature distribution shifted to the high-temperature direction (Figure 2).
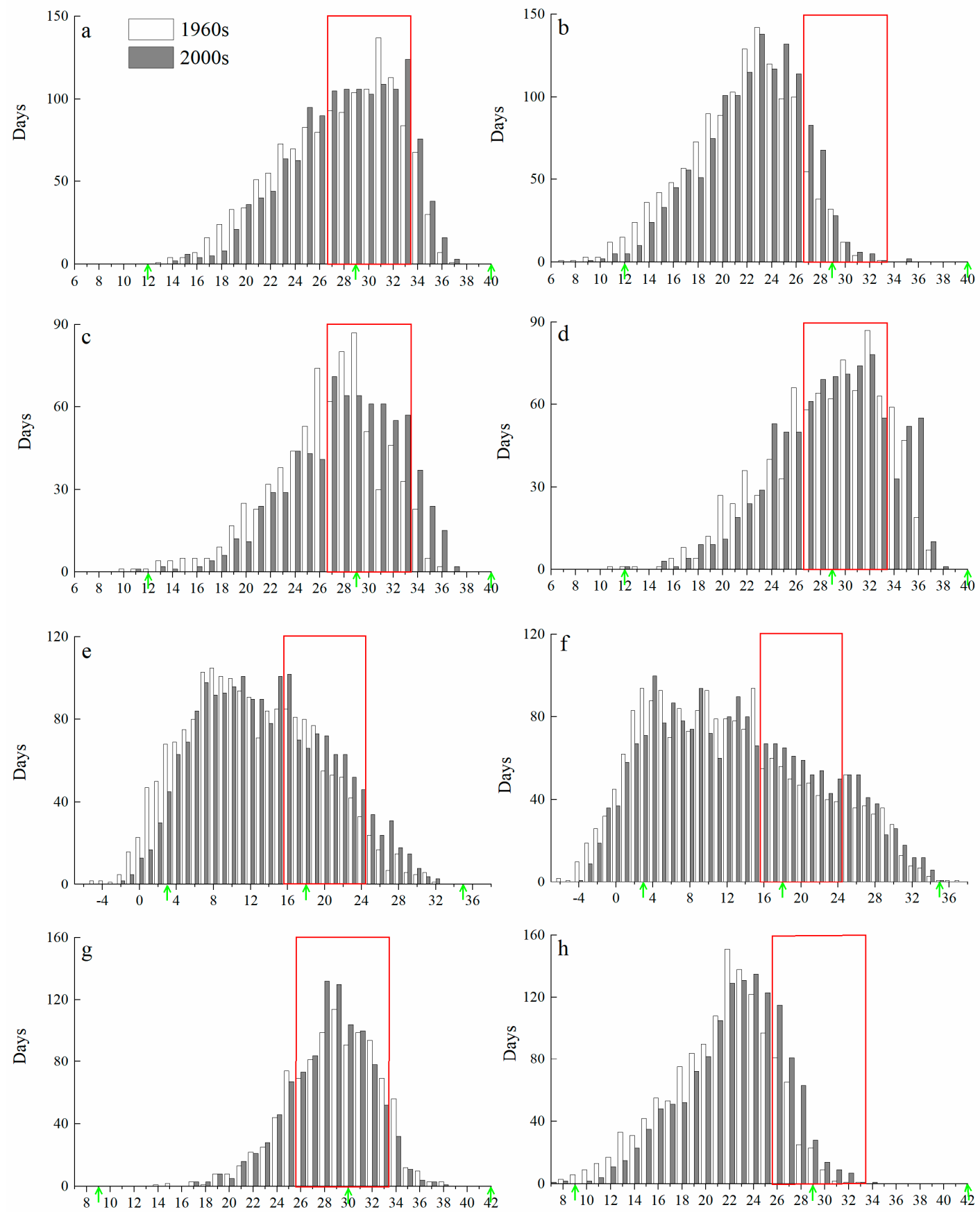

Figure 2. Frequency distributions of daytime temperatures for the 1960s (1960-1969) and 2000s (2000-2009) for the whole growing seasons of different crops at different sites: (a) rice, Changshu; (b) single rice, Sanjiang; (c) early rice, Taoyuan; (d) late rice, Taoyuan; (e) winter wheat, Changshu; (f) winter wheat, Fengqiu; (g) summer maize, Fengqiu; (h) spring maize, Hailun. The three green arrows in each graph represent the base, optimum and maximum temperatures, respectively, for crop photosynthesis, and the red rectangles highlight ranges of the optimum temperatures for crop photosynthesis. 
Compared to the 1960s, during the 2000s, the number of days with extremely low temperatures occurring in rice areas of Changshu in East China (Figure 2a) and in early (Figure 2c) and late rice (Figure 2d) areas of Taoyuan in Central China did not change significantly during growth periods, but the number of days with high temperatures of over $35^{\circ} \mathrm{C}$ significantly increased from 73 to 118 days for late rice areas in Taoyuan (Figure 2d). While the number of optimum temperature days for early rice in Taoyuan slightly increased, numbers for rice in Changshu and late rice in Taoyuan showed no significant changes in the 2000s. However, the number of extremely low temperature days decreased from 36 to 13 days during single cropping rice growth periods in Sanjiang, Northeast China (Figure $2 b$ ), which was accompanied by an increase in the number of optimum temperature days (from 142 to 203 days), and the number of extremely high temperature days did not change significantly between the two periods. For wheat (Figure 2e,f), in Changshu in East China (Figure 2e) and Fengqiu in North China (Figure 2f), the number of low temperature days during the growth period in the 2000s decreased significantly relative to the 1960s, with Changshu decreasing from 214 to 112 days and Fengqiu decreasing from 374 to 298 days. While the number of optimum temperature days increased, with Changshu increasing from 582 to 641 days and Fengqiu increasing from 489 to 570 days, the number of extremely high temperature days did not change significantly, which had a positive effect on wheat growth as compared to the 1960s. For maize (Figure 2g,h), temperatures in Fengqiu of North China (Figure 2g) did not change significantly during the two growth periods, nor did the temperature frequency distribution, the number of extremely high and low temperature days or the number of optimum temperature days. For summer maize in Hailun in Northeast China (Figure 2h), the number of optimum temperature days significantly increased from 207 days in the 1960s to 318 days in the 2000s, while extremely high temperatures did not occur in the two periods.

According to these results, the number of low temperature days decreased, and the number of optimum temperature days increased significantly for winter wheat in North and East China, rice and maize in Northeast China. The number of optimum temperature days did not change significantly for rice in South China, and the number of extremely high temperature days increased (Figure 2).

\subsection{Effects of Warming on Crop Photosynthesis, Respiration and Net Primary Productivity}

Crop responses to temperature change in different rotation systems showed great regional variations. Figure 3 showed the photosynthesis production simulation results for the three studied crops for the 1960s and 2000s where GPP denoted carbon accumulated by photosynthesis, RA denoted carbon lost by crop autotrophic respiration and Biomass denoted the net accumulation of crop above ground biomass (AGB). According to the results, effects of climate warming on crop photosynthetic production differed in different regions. Warming made few contributions to AGB increases for rice in Southern China. When increases in GPP brought by warming were less than carbon losses brought by RA, AGB did not increase and slightly decreased (e.g., late rice in Taoyuan). By contrast, rice AGB increased slightly in Sanjiang in Northeast China (from $518 \mathrm{gC} \mathrm{m}^{-2}$ in the 1960s to $559 \mathrm{gC} \mathrm{m}^{-2}$ in the 2000s). For winter wheat in North and East China, temperature increases resulted in different degrees of increases in carbon accumulated by photosynthesis and carbon consumed by respiration in the two regions, and the carbon increment assimilated by photosynthesis was much higher than that consumed by respiration, causing AGB to increase significantly (with Changshu in East China increasing from 425 to $621 \mathrm{gC} \mathrm{m}^{-2}$ and Fengqiu in North China increasing from 341 to $544 \mathrm{gC} \mathrm{m}^{-2}$ during the 1960s to 2000s). The increase in temperature led to a significant increase in GPP of spring maize in Hailun in Northeast China (from 859 to $1054 \mathrm{gC} \mathrm{m}^{-2}$ ), but RA did not increase significantly, leading to a significant increase in AGB (from 601 to $743 \mathrm{gC} \mathrm{m}^{-2}$ ). However, the AGB for summer maize in Fengqiu in North China showed no significant changes, which was consistent with the temperature change. 

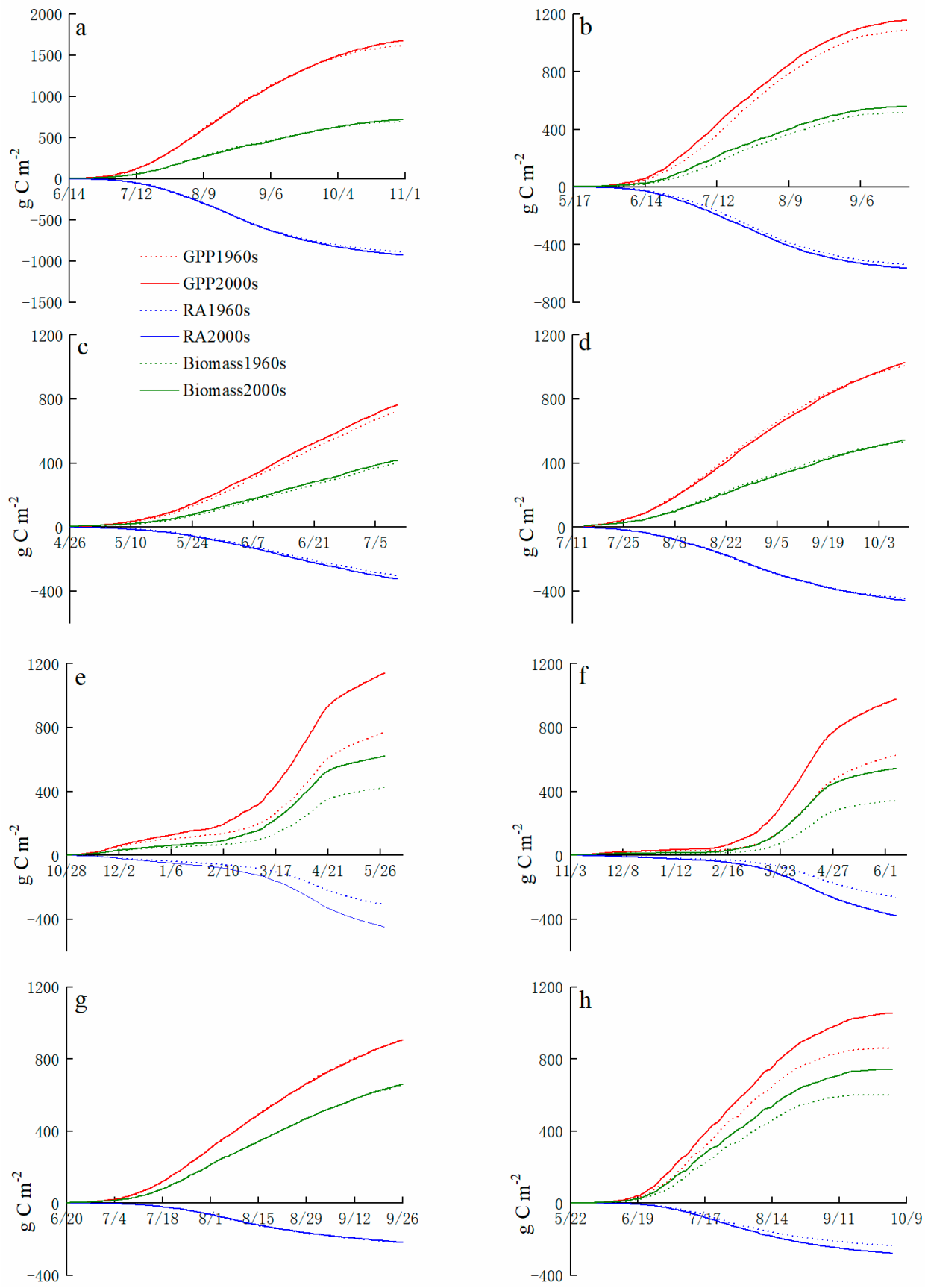

Figure 3. Simulated crop gross primary productivity (GPP), respiration (RA) and above ground biomass (AGB) (g C m ${ }^{-2}$ ) for the 1960s and 2000s: (a) rice, Changshu, Jiangsu province; (b) single rice, Sanjiang, Heilongjiang province; (c) early rice, Taoyuan, Hunan province; (d) late rice, Taoyuan, Hunan province; (e) winter wheat, Changshu, Jiangsu province; (f) winter wheat, Fengqiu, Henan province; (g) summer maize, Fengqiu, Henan province; (h) spring maize, Hailun, Heilongjiang province. Red, blue and green lines, respectively, represent simulated GPP, RA and AGB values for the two periods, and dashed lines pertain to the 1960s, while solid lines pertain to the 2000s.

\subsection{Temperature Change Effects on Crop Productivity in Key Growth Periods}

A comparison of the key growth periods before and after heading (silking) (Table 4) showed that relative to the 1960s, the daily mean temperatures in the vegetative growth stage before heading (silking) and in the reproductive growth stage after heading (silking) almost always increased in the 2000s, except for the maize in Fengqiu during the vegetative growth period (from $27.6{ }^{\circ} \mathrm{C}$ in the $1960 \mathrm{~s}$ to $27.1^{\circ} \mathrm{C}$ in the 2000s), but the distribution 
of optimum temperature days was different. Compared to the 1960s, the number of optimum temperature days increased 30 days before heading for Early rice in Taoyuan which was offset by the 15 days decrease in optimum temperature days after heading in the 2000s. Similarly, for Late rice in Taoyuan, compared to the 1960s, the number of optimum temperature days decreased 42 days before heading, which was offset by the 45 day increase in optimum temperature days after heading in the 2000s. All of the above resulted in few changes in the AGB of rice in South China (Table 4). However, the increase in optimum temperature days before and after heading for rice in Sanjiang made virtually the equal contribution to the increase in AGB in the two growth periods. The observed increase in AGB for winter wheat in North and East China was mainly attributable to a significant increase in the number of days with optimum temperatures before heading. In the 1960s, there were 124 optimum temperature days before heading in North China, and this number increased to 190 days in the 2000s. For winter wheat in East China, there were 90 optimum temperature days before heading in the 1960s, and this number increased to 162 days in the 2000s. However, no significant differences in the number of optimum temperature days were found between the two periods after heading. Relative to the 1960s, summer maize in Fengqiu in North China in the 2000s experienced a minor change in temperatures before and after silking, and thus the AGB of maize in this region remained basically unchanged. For spring maize in Hailun in Northeast China, compared to the $1960 \mathrm{~s}$, the average temperature increased by $1.3^{\circ} \mathrm{C}$ before and after silking in the 2000s. The number of optimum temperature days before and after silking increased by 61 and 57 days, respectively, leading to an increase in AGB both before and after silking. In general, warming before heading (silking) made more significant contributions to increases in AGB.

Table 4. Photosynthetic production and temperature changes in different growth periods for the 1960s and 2000s.

\begin{tabular}{|c|c|c|c|c|c|c|c|c|c|c|c|}
\hline \multirow[t]{2}{*}{ Crop } & \multirow[t]{2}{*}{ DVI } & \multicolumn{2}{|c|}{$\begin{array}{c}\mathrm{GPP}^{\mathrm{a}} \\
\left(\mathrm{gC} \mathrm{m}^{-2}\right)\end{array}$} & \multicolumn{2}{|c|}{$\begin{array}{c}\mathrm{RA}^{\mathrm{a}} \\
\left(\mathrm{gC} \mathrm{m}^{-2}\right)\end{array}$} & \multicolumn{2}{|c|}{$\begin{array}{c}\mathrm{AGB}^{\mathrm{a}} \\
\left(\mathrm{gC} \mathrm{m}^{-2}\right)\end{array}$} & \multicolumn{2}{|c|}{$\begin{array}{c}\text { Number of } \\
\text { days with } T_{0} \\
b\end{array}$} & \multicolumn{2}{|c|}{$\begin{array}{c}\mathrm{T}_{\text {mean }}{ }^{\mathrm{c}} \\
\left({ }^{\circ} \mathrm{C}\right)\end{array}$} \\
\hline & & 1960s & $2000 s$ & $1960 s$ & $2000 s$ & 1960s & $2000 s$ & 1960s & $2000 s$ & $1960 s$ & $2000 s$ \\
\hline \multirow{2}{*}{$\begin{array}{c}\text { Rice } \\
\text { (Changshu) }\end{array}$} & $\begin{array}{l}40 \text { days before } \\
\text { heading-heading }\end{array}$ & $\begin{array}{c}762 \\
(47.0 \%)\end{array}$ & $\begin{array}{c}745 \\
(44.4 \%)\end{array}$ & $\begin{array}{c}422 \\
(47.5 \%)\end{array}$ & $\begin{array}{c}422 \\
(45.5 \%)\end{array}$ & $\begin{array}{c}317 \\
(45.8 \%)\end{array}$ & $\begin{array}{c}305 \\
(42.6 \%)\end{array}$ & 333 & 280 & 28.4 & 28.6 \\
\hline & heading-maturity & $\begin{array}{c}666 \\
(41.1 \%)\end{array}$ & $\begin{array}{c}735 \\
(43.8 \%)\end{array}$ & $\begin{array}{c}383 \\
(43.1 \%)\end{array}$ & $\begin{array}{c}420 \\
(45.2 \%)\end{array}$ & $\begin{array}{c}283 \\
(40.9 \%)\end{array}$ & $\begin{array}{c}315 \\
(44.0 \%)\end{array}$ & 139 & 162 & 20.7 & 21.6 \\
\hline \multirow{2}{*}{$\begin{array}{l}\text { Single rice } \\
\text { (Sanjiang) }\end{array}$} & $\begin{array}{l}40 \text { days before } \\
\text { heading-heading }\end{array}$ & $\begin{array}{c}560 \\
(51.5 \%)\end{array}$ & $\begin{array}{c}588 \\
(50.8 \%)\end{array}$ & $\begin{array}{c}271 \\
(50.4 \%)\end{array}$ & $\begin{array}{c}282 \\
(50.0 \%)\end{array}$ & $\begin{array}{c}265 \\
(51.2 \%)\end{array}$ & $\begin{array}{c}282 \\
(50.5 \%)\end{array}$ & 74 & 76 & 21.1 & 21.8 \\
\hline & heading-maturity & $\begin{array}{c}404 \\
(37.2 \%)\end{array}$ & $\begin{array}{c}421 \\
(36.4 \%)\end{array}$ & $\begin{array}{c}210 \\
(39.0 \%)\end{array}$ & $\begin{array}{c}217 \\
(38.5 \%)\end{array}$ & $\begin{array}{c}194 \\
(37.6 \%)\end{array}$ & $\begin{array}{c}204 \\
(36.6 \%)\end{array}$ & 12 & 33 & 17.7 & 18.2 \\
\hline \multirow{2}{*}{$\begin{array}{l}\text { Early rice } \\
\text { (Taoyuan) }\end{array}$} & $\begin{array}{c}40 \text { days before } \\
\text { heading-heading }\end{array}$ & $\begin{array}{c}398 \\
(54.9 \%)\end{array}$ & $\begin{array}{c}423 \\
(55.3 \%)\end{array}$ & $\begin{array}{c}166 \\
(54.7 \%)\end{array}$ & $\begin{array}{c}175 \\
(54.2 \%)\end{array}$ & $\begin{array}{c}210 \\
(52.4 \%)\end{array}$ & $\begin{array}{c}225 \\
(53.6 \%)\end{array}$ & 168 & 198 & 23.2 & 24.2 \\
\hline & heading-maturity & $\begin{array}{c}309 \\
(42.6 \%)\end{array}$ & $\begin{array}{c}317 \\
(41.5 \%)\end{array}$ & $\begin{array}{c}131 \\
(43.1 \%)\end{array}$ & $\begin{array}{c}139 \\
(43.1 \%)\end{array}$ & $\begin{array}{c}178 \\
(44.3 \%)\end{array}$ & $\begin{array}{c}178 \\
(42.5 \%)\end{array}$ & 171 & 156 & 26.8 & 28.7 \\
\hline \multirow{2}{*}{$\begin{array}{l}\text { Late rice } \\
\text { (Taoyuan) }\end{array}$} & $\begin{array}{c}40 \text { days before } \\
\text { heading-heading }\end{array}$ & $\begin{array}{c}584 \\
(58.0 \%)\end{array}$ & $\begin{array}{c}565 \\
(54.9 \%)\end{array}$ & $\begin{array}{c}267 \\
(59.8 \%)\end{array}$ & $\begin{array}{c}262 \\
(57.0 \%)\end{array}$ & $\begin{array}{c}294 \\
(55.0 \%)\end{array}$ & $\begin{array}{c}281 \\
(51.6 \%)\end{array}$ & 281 & 239 & 28.0 & 28.1 \\
\hline & heading-maturity & $\begin{array}{c}362 \\
(36.0 \%)\end{array}$ & $\begin{array}{c}404 \\
(39.2 \%)\end{array}$ & $\begin{array}{c}157 \\
(35.2 \%)\end{array}$ & $\begin{array}{c}175 \\
(38.2 \%)\end{array}$ & $\begin{array}{c}205 \\
(38.4 \%)\end{array}$ & $\begin{array}{c}229 \\
(41.9 \%)\end{array}$ & 111 & 156 & 22.0 & 23.3 \\
\hline \multirow{2}{*}{$\begin{array}{l}\text { Winter wheat } \\
\text { (Fengqiu) }\end{array}$} & $\begin{array}{c}40 \text { days before } \\
\text { heading-heading }\end{array}$ & $\begin{array}{c}339 \\
(54.2 \%)\end{array}$ & $\begin{array}{c}503 \\
(51.4 \%)\end{array}$ & $\begin{array}{c}111 \\
(42.3 \%)\end{array}$ & $\begin{array}{c}160 \\
(42.2 \%)\end{array}$ & $\begin{array}{c}211 \\
(61.8 \%)\end{array}$ & $\begin{array}{c}317 \\
(58.2 \%)\end{array}$ & 124 & 190 & 11.2 & 13.4 \\
\hline & heading-maturity & $\begin{array}{c}136 \\
(21.8 \%)\end{array}$ & $\begin{array}{c}184 \\
(18.8 \%) \\
\end{array}$ & $\begin{array}{c}82 \\
(31.1 \%) \\
\end{array}$ & $\begin{array}{c}104 \\
(27.5 \%) \\
\end{array}$ & $\begin{array}{c}54 \\
(15.9 \%) \\
\end{array}$ & $\begin{array}{c}80 \\
(14.7 \%) \\
\end{array}$ & 200 & 208 & 20.8 & 21.5 \\
\hline \multirow{2}{*}{$\begin{array}{l}\text { Winter wheat } \\
\text { (Changshu) }\end{array}$} & $\begin{array}{l}40 \text { days before } \\
\text { heading-heading }\end{array}$ & $\begin{array}{c}351 \\
(45.6 \%)\end{array}$ & $\begin{array}{c}531 \\
(46.5 \%)\end{array}$ & $\begin{array}{c}115 \\
(37.3 \%)\end{array}$ & $\begin{array}{c}176 \\
(39.1 \%)\end{array}$ & $\begin{array}{c}217 \\
(51.1 \%)\end{array}$ & $\begin{array}{c}324 \\
(52.2 \%)\end{array}$ & 90 & 162 & 10.8 & 13.0 \\
\hline & heading-maturity & $\begin{array}{c}209 \\
(27.2 \%)\end{array}$ & $\begin{array}{c}271 \\
(23.7 \%)\end{array}$ & $\begin{array}{c}108 \\
(35.0 \%)\end{array}$ & $\begin{array}{c}143 \\
(32.0 \%)\end{array}$ & $\begin{array}{c}101 \\
(23.8 \%)\end{array}$ & $\begin{array}{c}128 \\
(20.5 \%)\end{array}$ & 234 & 256 & 18.3 & 19.9 \\
\hline
\end{tabular}


Table 4. Cont.

\begin{tabular}{|c|c|c|c|c|c|c|c|c|c|c|c|}
\hline \multirow[t]{2}{*}{ Crop } & \multirow[t]{2}{*}{ DVI } & \multicolumn{2}{|c|}{$\begin{array}{c}\mathrm{GPP}^{\mathrm{a}} \\
\left(\mathrm{gC} \mathrm{m}^{-2}\right)\end{array}$} & \multicolumn{2}{|c|}{$\begin{array}{c}\mathrm{RA}^{\mathrm{a}} \\
\left(\mathrm{gC} \mathrm{m}^{-2}\right)\end{array}$} & \multicolumn{2}{|c|}{$\begin{array}{c}\mathrm{AGB}^{\mathrm{a}} \\
\left(\mathrm{gC} \mathrm{m}^{-2}\right)\end{array}$} & \multicolumn{2}{|c|}{$\begin{array}{l}\text { Number of } \\
\text { days with } T_{0} \\
b\end{array}$} & \multicolumn{2}{|c|}{$\begin{array}{c}\mathrm{T}_{\text {mean }}{ }^{\mathrm{c}} \\
\left({ }^{\circ} \mathrm{C}\right)\end{array}$} \\
\hline & & $1960 s$ & $2000 s$ & $1960 \mathrm{~s}$ & $2000 s$ & $1960 \mathrm{~s}$ & $2000 s$ & 1960s & $2000 s$ & $1960 \mathrm{~s}$ & $2000 s$ \\
\hline \multirow{2}{*}{$\begin{array}{l}\text { Summer } \\
\text { maize } \\
\text { (Fengqiu) }\end{array}$} & $\begin{array}{l}40 \text { days before } \\
\text { silking-silking }\end{array}$ & $\begin{array}{c}392 \\
(43.1 \%)\end{array}$ & $\begin{array}{c}387 \\
(42.3 \%)\end{array}$ & $\begin{array}{c}94 \\
(42.7 \%)\end{array}$ & $\begin{array}{c}90 \\
(41.3 \%)\end{array}$ & $\begin{array}{c}269 \\
(40.8 \%)\end{array}$ & $\begin{array}{c}269 \\
(40.3 \%)\end{array}$ & 332 & 352 & 27.6 & 27.1 \\
\hline & silking-maturity & $\begin{array}{c}505 \\
(55.6 \%)\end{array}$ & $\begin{array}{c}515 \\
(56.3 \%)\end{array}$ & $\begin{array}{c}125 \\
(56.7 \%)\end{array}$ & $\begin{array}{c}127 \\
(58.0 \%)\end{array}$ & $\begin{array}{c}380 \\
(57.7 \%)\end{array}$ & $\begin{array}{c}388 \\
(58.2 \%)\end{array}$ & 276 & 279 & 23.3 & 23.5 \\
\hline \multirow{2}{*}{$\begin{array}{l}\text { Spring maize } \\
\text { (Hailun) }\end{array}$} & $\begin{array}{l}40 \text { days before } \\
\text { silking-silking }\end{array}$ & $\begin{array}{c}348 \\
(46.2 \%)\end{array}$ & $\begin{array}{c}386 \\
(45.0 \%)\end{array}$ & $\begin{array}{c}83 \\
(39.8 \%)\end{array}$ & $\begin{array}{c}92 \\
(38.9 \%)\end{array}$ & $\begin{array}{c}250 \\
(46.7 \%)\end{array}$ & $\begin{array}{c}285 \\
(45.5 \%)\end{array}$ & 149 & 210 & 20.6 & 21.9 \\
\hline & silking-maturity & $\begin{array}{c}383 \\
(50.9 \%)\end{array}$ & $\begin{array}{c}445 \\
(52.0 \%)\end{array}$ & $\begin{array}{c}122 \\
(58.2 \%)\end{array}$ & $\begin{array}{c}139 \\
(59.2 \%)\end{array}$ & $\begin{array}{c}261 \\
(49.0 \%)\end{array}$ & $\begin{array}{c}306 \\
(48.8 \%)\end{array}$ & 83 & 140 & 16.2 & 17.5 \\
\hline
\end{tabular}

a 10-year average value for the accumulation of GPP, RA and AGB for certain DVIs for the 1960s and 2000s. Accumulation within a certain DVI accounting for the value for the whole growth period is shown in brackets; ${ }^{b} 10$-year total number of days with $\mathrm{T}_{\mathrm{O}}$ for the $1960 \mathrm{~s}$ and $2000 \mathrm{~s} ;{ }^{\mathrm{c}} 10$-year average $\mathrm{T}_{\text {mean }}$ value for the 1960s and 2000s.

Figure 4 shows the correlation between the change in the number of optimum temperature days and the AGB of different crops in the two key growth stages for rice, wheat and maize in the 1960s and 2000s. Changes in the number of optimum temperature days and AGB refer to differences in the number of optimum temperature days and in AGB in Table 4 between the 2000s and 1960s. Relative to the 1960s, the increase in the number of optimum temperature days in the 2000s not only improved crop productivity but also led to a significantly nonlinear positive correlation between crop AGB and the number of optimum temperature days (Figure 4). For example, the period from silking to maturity for spring maize in Hailun increased by 5.7 days on average, and AGB increased by $45 \mathrm{~g}$ $\mathrm{C} / \mathrm{m}^{2}$ in the same period. By contrast, in the 2000s, the number of optimum temperatures days before heading decreased by 5.3 days, and over the same period, AGB decreased by $12 \mathrm{~g} \mathrm{C} / \mathrm{m}^{2}$ for Changshu rice (Table 4 ).

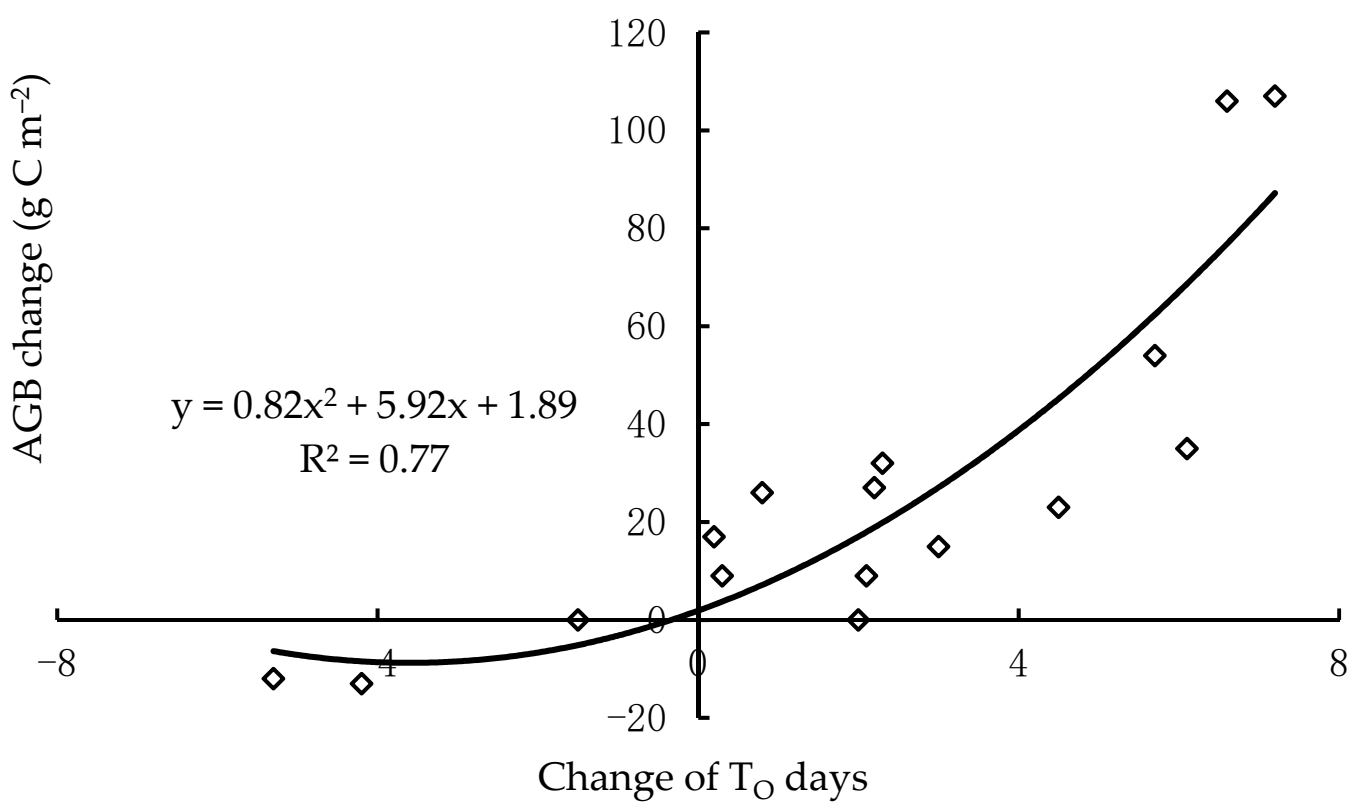

Figure 4. Relationship between the change in $\mathrm{T}_{\mathrm{O}}$ days and aboveground biomass (AGB).

\section{Discussion}

Climate warming had been perceived to shorten the duration of crop growing period provided that crops had constant thermal requirements. In multiple cropping systems, such 
as wheat/maize, wheat/rice and rice/rice rotations, the crops were planted and harvested subsequently in a year-long period. The crop phenology changes were restricted not only by climate warming but also by the crop rotation systems at a specific location. In single cropping systems (Hailun and Sanjiang of the present study), warming has the effect of potentially prolonging the growing duration of crops [6]. In this study, our attention was on crops' physiological responses to temperature changes in their vegetative and reproductive stages. The fixed crop phenology assumption was only for simplicity of the accumulated temperature calculation when we faced complicated crop phenology changes at different locations. We were aware that taking into consideration the phenology changes would make the calculation of the accumulated temperature more accurate. However, the possible changes of the planting date of the first crop (e.g., wheat in the wheat/maize rotation) and the harvesting date of the second crop (e.g., maize in the wheat/maize rotation) occurred on dates of low temperatures. Incorporation of the phenology changes makes no obvious differences in the accumulated temperatures.

Compared to previous research results, it can be found that the response to climate warming of the three staple crops was qualitatively consistent with them $[39,40]$. Taking the rice in Northeast China for example, climate warming contributed $23.2 \%$ 28.8\% to the increase in rice yield in Heilongjiang province [39]. The yield of winter wheat in Henan province from 1961 to 1981 was also significantly correlated with climate warming, and in 1991-2000 and 2001-2007, the increment of yield due to temperature increase accounted for $15.6 \% \sim 20.7 \%$ of the actual increment [40]. Crop adaptability to local temperatures in the two periods resulted in regional differences in crop photosynthetic productivity. Relative to the 1960s, the temperature distribution of crops growing periods in each rotation area shifted towards high-temperature regions in the 2000s (Figure 2), but significant differences in the adaptability of different crops to environmental temperature changes were found. Climate warming was generally believed to reduce yields when they exceeded an optimum level, but they can increase crops yields in cool regions where temperatures were well below the optimum level $[1,2,36]$. The temperatures in South China have been high in the past. Further increase in temperature should lead to more high temperature days of above $35{ }^{\circ} \mathrm{C}$ during the growth period, placing more high temperature stress on rice growth [41]. Thus, the positive effect of climate warming on crops in this region was not obvious. Temperatures in winter wheat planting areas of North and Northeast China increased significantly as well as the number of days with optimum temperatures. As temperature increases mainly occurred in the winter and spring [42] and the winter wheat growth period crossed the two seasons with the most obvious climate warming, the observed increase in temperature before heading contributed significantly to the AGB increase for winter wheat (Table 4).

Our simulations did not consider adaptive adjustments and crop variety changes, which may potentially introduce uncertainties when assessing impacts of climate warming. In terms of adaptation to global warming, for example, changing sowing dates or cultivars has been suggested by several studies to compensate for negative impacts of increasing temperatures [43]. Over recent decades, there have been many changes in agronomic activities, including the use of renewed cultivars [44,45], optimized fertilizers [46], expanded irrigation [47], and prolonged growing periods [48]. These non-climatic factors have contributed to observed changes in crop productivity in recent decades $[3,46,49]$. In this study, the changes of crop management practices were not considered in the modelling analysis when we intendedly analyzed the potential impacts of climate warming on crop growth. The absence of detailed information on past management and cultivar improvements has been the big challenge to parameterize the adaptive management and variety renewal effects with modelling methods. Other future adaptations, such as crop cultivation shifting to higher latitudes, should also be the following step in consideration.

Crops are sensitive to climate change, including changes in temperature and precipitation, and to rising atmospheric $\mathrm{CO}_{2}$ concentrations [1]. To investigate the effects of warming on crop growth, it is necessary to isolate the effects of individual factors from 
possible impacts on crop productivity. There are studies focusing on effects of temperature changes on crop growth as one of the most direct negative impacts from climate change on crops $[1,50]$ without considering other possible climate change effects resulting from elevated atmospheric $\mathrm{CO}_{2}$ concentrations or changes in precipitation, rendering it unrepresentative of realistic climate change scenarios. While not considered here, the process-based model Agro- $\mathrm{C}$ is able to account for effects of elevated $\mathrm{CO}_{2}$. However, considerable uncertainties exist with respect to $\mathrm{CO}_{2}$ fertilization effects on crop growth, which could alleviate negative impacts of warming to a certain extent. Additionally, while associated impacts of changes in precipitation under climate change were not considered in this study, we assumed that crops were not water-limited in our simulation, which was in fact reality when irrigation infrastructure developed well in the study sites.

\section{Conclusions}

Using the Agro-C model, we illustrated the effects of climate warming on photosynthesis and respiration of crops in typical cropping systems in China. We found that crop growth responses to temperature increase differed under different crop rotation systems in China. The AGB of rice and maize in Northeast China, winter wheat in North China and East China were positively correlated with climate warming, but the AGB of rice in South China showed no significant changes. Relative to the 1960s, the number of the optimum temperature days during crop growth in different regions increased in the 2000s, and a positive correlation was found between crop photosynthetic productivity and the number of the optimum temperature days. Moreover, warming before heading (silking) made more significant contributions to increases in AGB, especially for winter wheat.

Author Contributions: Conceptualization and methodology-W.Z.; writing preparation review and editing and visualization-Q.Z.; analysis, investigation and resources-Y.Y.; methodology, analysis and supervision-T.L. and L.Y. All authors have read and agreed to the published version of the manuscript.

Funding: This study was jointly supported by the National Key R\&D Program of China (2017YFE0104600) and National Natural Science Foundation of China (Grant Nos. 41605088, 41975118).

Data Availability Statement: The data presented in this study are available on request from the corresponding author.

Acknowledgments: We gratefully acknowledge the atmosphere and biology sub-centers of CERN for data support.

Conflicts of Interest: The authors declare no conflict of interest.

\section{References}

1. Zhao, C.; Piao, S.; Huang, Y.; Wang, X.; Ciais, P.; Huang, M.; Zeng, Z.; Peng, S. Field warming experiments shed light on the wheat yield response to temperature in China. Nat. Commun. 2016, 7, 13530. [CrossRef]

2. Wang, X.; Zhao, C.; Müller, C.; Wang, C.; Ciais, P.; Janssens, I.; Peñuelas, J.; Asseng, S.; Li, T.; Elliott, J.; et al. Emergent constraint on crop yield response to warmer temperature from field experiments. Nat. Sustain. 2020, 3, 908-916. [CrossRef]

3. Yu, Y.Q.; Huang, Y.; Zhang, W. Changes in rice yields in China since 1980 associated with cultivar improvement, climate and crop management. Field Crop Res. 2012, 136, 65-75. [CrossRef]

4. Zhang, T.Y.; Zhu, J.A.; Wassmann, R. Responses of rice yields to recent climate change in China: An empirical assessment based on long-term observations at different spatial scales (1981-2005). Agric. For. Meteorol. 2010, 150, 1128-1137. [CrossRef]

5. Tao, F.L.; Yokozawa, M.; Liu, J.Y.; Zhang, Z. Climate-crop yield relationships at provincial scales in China and the impacts of recent climate trends. Clim. Res. 2008, 38, 83-94. [CrossRef]

6. Tao, F.L.; Yokozawa, M.; Xu, Y.L.; Hayashi, Y.; Zhang, Z. Climate changes and trends in phenology and yields of field crops in China, 1981-2000. Agric. For. Meteorol. 2006, 138, 82-92. [CrossRef]

7. Li, S.A.; Wheeler, T.; Challinor, A.; Lin, E.; Ju, H.; Xu, Y.L. The observed relationships between wheat and climate in China. Agric. For. Meteorol. 2010, 150, 1412-1419. [CrossRef]

8. Zhang, T.Y.; Huang, Y. Impacts of climate change and inter-annual variability on cereal crops in China from 1980 to 2008. J. Sci. Food Agric. 2012, 92, 1643-1652. [CrossRef] [PubMed]

9. Jiang, X.J.; Tang, L.; Liu, X.J.; Cao, W.X.; Zhu, Y. Spatial and Temporal Characteristics of Rice Potential Productivity and Potential Yield Increment in Main Production Regions of China. J. Integr. Agric. 2013, 12, 45-56. [CrossRef] 
10. Liu, B.H.; Xu, M.; Henderson, M.; Qi, Y.; Li, Y.Q. Taking China's temperature: Daily range, warming trends, and regional variations, 1955-2000. J. Clim. 2004, 17, 4453-4462. [CrossRef]

11. Peng, S.B.; Khush, G.S.; Virk, P.; Tang, Q.Y.; Zou, Y.B. Progress in ideotype breeding to increase rice yield potential. Field Crop Res. 2008, 108, 32-38. [CrossRef]

12. Zhang, T.Y.; Huang, Y.; Yang, X.G. Climate warming over the past three decades has shortened rice growth duration in China and cultivar shifts have further accelerated the process for late rice. Glob. Chang. Biol. 2013, 19, 563-570. [CrossRef] [PubMed]

13. Zhang, T.Y.; Yang, X.G.; Wang, H.S.; Li, Y.; Ye, Q. Climatic and technological ceilings for Chinese rice stagnation based on yield gaps and yield trend pattern analysis. Glob. Chang. Biol. 2014, 20, 1289-1298. [CrossRef] [PubMed]

14. Asseng, S.; Ewert, F.; Martre, P.; Rotter, R.P.; Lobell, D.B.; Cammarano, D.; Kimball, B.A.; Ottman, M.J.; Wall, G.W.; White, J.W. Rising temperatuRes. reduce global wheat production. Nat. Clim. Chang. 2015, 5, 143-147. [CrossRef]

15. Jiang, Y.; Yin, X.; Wang, X.; Zhang, L.; Lu, Z.; Lei, Y.; Chu, Q.; Chen, F. Impacts of global warming on the cropping systems of China under technical improvements from 1961 to 2016. Agron. J. 2020. [CrossRef]

16. Eitzinger, J.; Zalud, Z.; Alexandrov, V.; Van Diepen, C.A.; Trnka, M.; Dubrovsky, M.; Semeradova, D.; Oberforster, M. A local simulation study on the impact of climate change on winter wheat production in north-eastern Austria. Boden-kultur 2001, 52, 279-292.

17. Tao, F.L.; Hayashi, Y.; Zhang, Z.; Sakamoto, T.; Yokozawa, M. Global warming, rice production, and water use in Chi-na: Developing a probabilistic assessment. Agric. For. Meteorol. 2008, 148, 94-110. [CrossRef]

18. Liu, Z.J.; Hubbard, K.G.; Lin, X.M.; Yang, X.G. Negative effects of climate warming on maize yield are reversed by the changing of sowing date and cultivar selection in Northeast China. Glob. Chang. Biol. 2013, 19, 3481-3492. [CrossRef]

19. Liu, Z.J.; Yang, X.G.; Hubbard, K.G.; Lin, X.M. Maize potential yields and yield gaps in the changing climate of northeast China. Glob. Chang. Biol. 2012, 18, 3441-3454. [CrossRef]

20. Wang, J.; Wang, E.L.; Yang, X.G.; Zhang, F.S.; Yin, H. Increased yield potential of wheat-maize cropping system in the North China Plain by climate change adaptation. Clim. Chang. 2012, 113, 825-840. [CrossRef]

21. Lv, Z.F.; Liu, X.J.; Cao, W.X.; Zhu, Y. Climate change impacts on regional winter wheat production in main wheat production regions of China. Agric. For. Meteorol. 2013, 171, 234-248. [CrossRef]

22. Schlenker, W.; Roberts, M.J. Nonlinear temperature effects indicate severe damages to US crop yields under climate change. Proc. Natl. Acad. Sci. USA 2009, 106, 15594-15598. [CrossRef] [PubMed]

23. Welch, J.R.; Vincent, J.R.; Auffhammer, M.; Moya, P.F.; Dobermann, A.; Dawe, D. Rice yields in tropical/subtropical Asia exhibit large but opposing sensitivities to minimum and maximum temperatures. Proc. Natl. Acad. Sci. USA 2010, 107, 14562-14567. [CrossRef] [PubMed]

24. Deryng, D.; Sacks, W.J.; Barford, C.C.; Ramankutty, N. Simulating the effects of climate and agricultural management practices on global crop yield. Glob. Biogeochem. Cycles 2011, 25. [CrossRef]

25. Liu, Y.J.; Lin, E.D. Effects of Climate Change on Agriculture in Different Regions of China. Adv. Clim. Chang. Res. 2007, 3, 229-233.

26. Xiao, G.J.; Zhang, Q.; Wang, J. Impact of global climate change on agro-ecosystem: A review. Chin. J. Appl. Ecol. 2007, $18,1877-1885$.

27. Xiong, W.; Conway, D.; Lin, E.D.; Holman, I. Potential impacts of climate change and climate variability on China's rice yield and production. Clim. Res. 2009, 40, 23-35. [CrossRef]

28. Chavas, D.R.; Izaurralde, R.C.; Thomson, A.M.; Gao, X.J. Long-term climate change impacts on agricultural productivity in eastern China. Agric. For. Meteorol. 2009, 149, 1118-1128. [CrossRef]

29. Lin, E.D.; Xiong, W.; Ju, H.; Xu, Y.L.; Li, Y.; Bai, L.P.; Xie, L.Y. Climate change impacts on crop yield and quality with $\mathrm{CO}_{2}$ fertilization in China. Philos. Trans. R. Soc. B 2005, 360, 2149-2154. [CrossRef]

30. Zhang, Q.; Zhang, W.; Li, T.T.; Sun, W.J.; Yu, Y.Q.; Wang, G. Projective analysis of staple food crop productivity in adaptation to future climate change in China. Int. J. Biometeorol. 2017, 8, 1-16. [CrossRef] [PubMed]

31. Huang, Y.; Yu, Y.Q.; Zhang, W.; Sun, W.J.; Liu, S.L.; Jiang, J.; Wu, J.S.; Yu, W.T.; Wang, Y.; Yang, Z.F. Agro-C: A biogeophysical model for simulating the carbon budget of agroecosystems. Agric. For. Meteorol. 2009, 149, 106-129. [CrossRef]

32. Tao, F.L.; Zhang, Z. Climate change, wheat productivity and water use in the North China Plain: A new super-ensemble-based probabilistic projection. Agric. For. Meteorol. 2013, 170, 255-271. [CrossRef]

33. Tao, F.L.; Zhang, Z. Impacts of climate change as a function of global mean temperature: Maize productivity and water use in China. Clim. Chang. 2011, 105, 409-432. [CrossRef]

34. Editorial Board. Agricultural Statistics of New China in Sixty Years; China Agricultrue Press: Beijing, China, 2009. (In Chinese)

35. Porter, J.R.; Gawith, M. TemperatuRes. and the growth and development of wheat: A review. Eur. J. Agron. 1999, 10, 23-36. [CrossRef]

36. Sanchez, B.; Rasmussen, A.; Porter, J.R. TemperatuRes. and the growth and development of maize and rice: A review. Glob. Chang. Biol. 2014, 20, 408-417. [CrossRef]

37. Thornton, P.; Hasenauer, H.; White, M. Simultaneous estimation of daily solar radiation and humidity from observed temperature and precipitation: An application over complex terrain in Austria. Agric. For. Meteorol. 2000, 104, 255-271. [CrossRef]

38. Zhang, W.; Huang, Y.; Sun, W.J.; Yu, Y.Q. Simulating crop net primary production in China from 2000 to 2050 by linking the crop-C model with a FGOALS's model climate change scenario. Adv. Atmos. Sci. 2007, 24, 845-854. [CrossRef] 
39. Fang, X.Q.; Wang, Y.; Xu, T.; Yun, Y.R. Contribution of Climate Warming to Rice Yield in Heilongjiang Province. Acta Geogr. Sin. 2004, 59, 820-828.

40. Cheng, L.; Liu, R.H.; Ma, Z.H. Influence of global warming on winter wheat yield in Henan Province. Chin. J. Eco-Agric. 2011, 19, 854-859. [CrossRef]

41. Cao, Y.Y.; Chen, Y.H.; Chen, M.; Wang, Z.Q.; Wu, C.F.; Bian, X.C.; Yang, J.C.; Zhang, J.H. Growth characteristics and endosperm structure of superior and inferior spikelets of indica rice under high-temperature stress. Biol. Plant 2016, 60, 532-542. [CrossRef]

42. Ding, Y.H.; Ren, G.Y.; Shi, G.Y.; Gong, P.; Zheng, X.H.; Zhai, P.M.; Zhang, D.E.; Zhao, Z.C.; Wang, S.W.; Wang, H.J.; et al. National Assessment Report of Climate Change (I): Climate change in China and its future trend. Adv. Clim. Chang. Res. 2006, 2, 3-8.

43. Butler, E.E.; Huybers, P.J. Adaptation of US maize to temperature variations. Nat. Clim. Chang. 2013, 3, 68-72. [CrossRef]

44. Zhou, Y.; He, Z.; Sui, X.X.; Xia, X.; Zhang, X.K.; Zhang, G.S. Genetic improvement of grain yield and associated traits in the Northern China winter wheat region from 1960 to 2000. Crop Sci. 2007, 47, 245-253. [CrossRef]

45. Liu, Y.; Wang, E.; Yang, X.; Wang, J. Contributions of climatic and crop varietal changes to crop production in the North China Plain, since 1980s. Glob. Chang. Biol. 2009, 16, 2287-2299. [CrossRef]

46. Huang, Y.; Zhang, W.; Sun, W.; Zheng, X. Net primary Production of Chinese croplands from 1950 to 1999. Ecol. Appl. 2007, 17, 692-701. [CrossRef]

47. Wang, F.; He, Z.; Sayre, K.D.; Li, S.; Si, J.; Feng, B.; Kong, L. Wheat cropping systems and technologies in China. Field Crop Res. 2009, 111, 181-188. [CrossRef]

48. Minoli, S.; Muller, C.; Elliott, J.; Ruane, A.C.; Jagermeyr, J.; Zabel, F.; Dury, M.; Folberth, C.; Francois, L.; Hank, T. Global response patterns of major rainfed crops to adaptation by maintaining current growing periods and irrigation. Earth's Future 2019, 7, 1464-1480. [CrossRef]

49. Song, Y.; Wang, C.; Ren, G.; Zhao, Y.; Linderholm, H.W. The relative contribution of climate and cultivar renewal to shaping rice yields in China since 1981. Theor. Appl. Climatol. 2015, 120,1-9. [CrossRef]

50. Ottman, M.J.; Kimball, B.A.; White, J.W.; Wall, G.W. Wheat Growth Response to Increased Temperature from Varied Planting Dates and Supplemental Infrared Heating. Agron. J. 2012, 104, 7-16. [CrossRef] 